\title{
ПРИХИЛЬНІСТЬ ЖІНОК ДО ДОВГОТРИВАЛОЇ ВТОРИННОЇ ПРОФІЛАКТИКИ ПІСЛЯ ІНФАРКТУ МІОКАРДА
}

\begin{abstract}
Резюме. Інфраркт міокарда (IM) є причиною високої смертності, інвалідизації та значних фрінансових витрат в усіх країнах світу. В Україні щорічно реєструють до 50 тис. випадків IM, 50 \% із цих пацієнтів помирають упродовж наступних 5 років. Тому оптимізація заходів вторинної профрілактики (модифрікація стилю життя, прихильність до подальшої медикаментозної терапії) має ключове значення у виживаності цих пацієнтів. Однак комплаєнсу при будь-яких захворюваннях вдається досягнути лише у 20-57 \% випадків, і за даними літератури, стать має вплив на його рівень.

Мета дослідження - багатофракторна оцінка прихильності жінок до лікування у післяінфарктний період.

Матеріали і методи. Обстежено 408 жінок із гострим коронарним синдромом віком від 46 до 94 років (середній вік $(71,30 \pm 0,44)$ року). Динаміку досліджуваних показників через 6; 12; 24 місяці вдалось простежити у 52 пацієнток. Відповідно до анкети Morisky-Green (D. E. Morisky, L. W. Green, 1986), виділено дві групи: перша (I) - прихильні 27 осіб - середній вік $(65,26 \pm 0,44)$ року та друга (II) - неприхильні 25 осіб - середній вік $(68,52 \pm 1,88)$ року. Далі проведено аналіз та оцінку клініко-лабораторних та інструментальних показників.

Результати досліджень та їх обговорення. В усіх жінок виявлено супутню патологію у поєднанні з артеріальною гіпертензією та цукровим діабетом 2 типу, надмірну масу тіла. Жінок першої групи швидше госпіталізували в стаціонар $(4 е р е з ~(15,37 \pm 4,9)$ год), ніж другої групи (через $(6,45 \pm 18,9)$ год) з більшою часткою реваскуляризації - 28,8 \% проти 5,7 \%; більшою масою некрозу міокарда; вищими вихідними показниками систолічного (САТ) та діастолічного (ДАТ) артеріального тиску - $(160 \pm 6,06)$ і $(95,6 \pm 2,66)$ проти $(153 \pm 6,11)$ і $(89,4 \pm 2,37)$ мм рт. ст. та нижчим рівнем загального холестерину $-(5,59 \pm 2,99)$ проти $(6,46 \pm 2,77)$ ммоль/л. У динаміці в цій групі виявлялось достовірне зниження частота серцевих скорочень (ЧСС), САТ та ДАТ та загального рівня холестерину та наближення показників ехокардіоскопії до притаманних для нормальної геометрії міокарда.

Висновки. У жінок спостерігається недостатній рівень прихильності до наступної вторинної просрілактики на амбулаторному етапі лікування і у більшості з них зберігається лише часткова прихильність, особливо через рік після перенесеного IM. Встановлено дуже низьку прихильність до немедикаментозних методів вторинної профілактики та заходів з корекції фракторів ризику і модифрікації стилю життя. Отримані результати ще раз вказують на необхідність оптимізації організаційно-профрілактичних заходів на амбулаторному етапі. Можлива стратегія переходу в роботі з пацієнтами від "комплаєнсу до конкордансу" дозволить покращити вторинну профілактику інфраркту міокарда.
\end{abstract}

Ключові слова: гострий коронарний синдром; інфраркт міокарда; комплаєнс; прихильність до лікування; вторинна профрілактика; ремоделювання серця.

ВстУп Питання вчасної діагностики, лікування та профрілактики інфраркту міокарда (IM) залишається актуальним і на сьогодні. Адже ця патологія є причиною високої смертності, інвалідизації і значних орінансових витрат як в Україні, так і за межами нашої держави [1-4]. щорічно реєструють до 50 тис. (у 2016 р. - 42 тис.) випадків IM, 50 \% із них помирають упродовж наступних 5 років [5]. А додаткові витрати у системі охорони здоров'я, такі, як повторні візити до лікарів, додаткові обстеження, нові призначення лікарських засобів, збільшення кількості госпіталізацій та інше, сягають до кількох сотень тисяч доларів чи євро на рік у різних зарубіжних країнах (J. E. Blair, 2008; B. A. Briesacher, 2008; G. Giamouzis, 2011; A. Bakhai, 2013).

Ці фракти визначають потребу в оптимізації заходів із вторинної профрілактики у післяінсрарктних хворих. Доведено (В. A. Franklin, 2008; S. Capewell, 2011), що належний контроль фракторів ризику за ефективністю прирівнюється до упровадження дороговартісних сучасних технологій діагностики та лікування, нових лікарських засобів, малоінвазивних методик та складних схем реорганізації охорони здоров'я. Модифікація стилю життя, подвійна антитромбоцитарна, ліпідознижувальна терапія та підтримання оптимального рівня артеріального тиску - усе це дає змогу значно подовжити життя пацієнтів та уникнути повторних ішемічних подій [6].

Однак якими б ефективними ліки не були, якщо хворий їх не приймає, то марно сподіватись на позитивний результат. Саме прихильність до такого лікування, переконання того, що призначена терапія рятує життя, активна участь пацієнта у боротьбі проти хвороби є визна- чальним у післяінсрарктний період. Аналіз досліджень у цьому напрямку вказує на вікову та гендерну невідповідність, пов'язану із комплаєнсом. Тому дані $є$ дуже суперечливими і важко зрозуміти як саме впливає на прихильність до подальшої терапії приналежність до жіночої статі, оскільки у більшості досліджень переважали особи чоловічої статі.

Метою дослідження стала багатосракторна оцінка прихильності жінок до лікування у післяінфрарктному періоді.

МАТЕРІАЛИ І МЕТОДИ Обстежено 408 жінок, які перебували на стаціонарному лікуванні в міському кардіологічному центрі. Усім пацієнткам проведено клініколабораторні, інструментальні обстеження та верифріковано діагноз ГКС $з$ елевацією/без елевації сегмента ST, згідно з рекомендаціями ESC, 2012, 2016. Повторні обстеження проводили через 3; 6; 12 місяців. У цілому вдалось простежити в динаміці дані 52 пацієнток. Прихильність до лікування оцінювали за анкетою MoriskyGreen (D. E. Morisky, L. W. Green, 1986). Прихильними вважали хворих, які набрали 4-3 бали, а неприхильними із кількістю балів 0-2. Статистичну обробку проводили за допомого пакета прикладних програм SPSS®V.21.0 та редактора електронних таблиць Excel. Дані представлено у формі середнього значення і стандартної похибки середнього (M $\pm m)$, із медіаною між 25-75 перцентилів, або як частота випадків у відсотках при нормальному розподілі. Достовірність відмінностей між групами за кількісними ознаками оцінювали за допомогою t-критерію Стьюдента (при нормальному розподілі), або в інших випадках використовували непараметричний ранговий 
критерії Манна-Уїтні. Відмінності були достовірними при рівні значимості >95\% $\%$ (р<0,05). В межах однієї групи динаміку оцінювали за допомогою парного t-критерію.

РЕЗУЛЬТАТИ ДОСЛІДЖЕНЬ ТА ЇХ ОБГОВОРЕННЯ Вік пацієнток був від 46 до 94 років, та у середньому становив $(71,30 \pm 0,44)$ року. Із клініко-анамнестичних даних відомо, що такі фактори ризику, як артеріальна гіпертензія (АГ) була наявна у 87,90 \%, цукровий діабет (ЦД) 2 типу - в $35 \%$, гіперхолестеринемія - у 44,90\%, тютюнокуріння - в 1,20\%, індекс маси тіла (IMT) >30 кг/ $\mathrm{M}^{2}$ - у 21,30 \% пацієнток.

Необхідно зазначити, що у 88 обстежених уже був первинний IM в анамнезі, у частини жінок й не один. Привертає увагу й те, що практично у всіх присутня коморбідна патологія (у 342 осіб, 83,80 \%). Найбільша частка супутньої патології припадала на хвороби органів травлення - 27,20 \% та судинні захворювання - 17,90 \%, трохи менша - на ревматичні та патології легень 10,30 \% та 7,40 \% відповідно. У 7,1\% пацієнток ІМ розвинувся на тлі хронічної фрібриляції передсердь. Окрім того також було діагностовано патологію щитоподібної залози (5,60 \%), несропатологію (2,30 \%) та перенесені онкологічні захворювання (4,90 \%). Варто зазначити, що при аналізі лабораторних даних практично у третини жінок рівень гемоглобіну був нижчим 120 г/л.

В обстежених пацієнток за локалізацією переважав інсраркт міокарда задньої стінки $(28,70 \%)$. Час, що пройшов від виникнення симптомів до госпіталізації, у середньому становив $(43,27 \pm 4,1)$ год, тобто пацієнтки досить пізно звертались за медичною допомогою. Це, у свою чергу, спричинило зниження рівня фармакоінвазивних методів відновлення кровотоку - лише у 11,02 \% було можливим застосування тромболізису, в 30,40 \% - перкутанне коронарне втручання (ПКВ).

Протягом госпітального періоду усім хворим призначено препарати базової терапії, відповідно до протоколів лікування, що існують (табл. 1), за винятком випадків, де ці засоби були протипоказані або неможливі через ускладнення. У цілому статини, ацетилсаліцилову кислоту, клопідогрель (тикагрелор) отримували 80-90 \% пацієнтів. Досить висока частота (близько 1/3) призначення сечогінних препаратів була зумовлена гострою лівошлуночковою недостатністю. Інгібітори АПФ та ß-блокатори призначали усім пацієнтам (за винятком протипоказань до них). У 50 \% випадків застосовували цитопротекторну терапію (корвітин, L-аргінін) у гострий період, на етапі реабілітаці - триметизиди, препарати мельдонію.
Після виписки усім пацієнтам були дані детальні рекомендації щодо корекції стилю життя, які стосувались раціонального харчування, відповідної фрізичної активності, відмови від тютюнокуріння, оптимізації маси тіла, досягнення цільового рівня артеріального тиску та ліпідів крові, а також наступного медикаментозного лікування, заснованого на даних доказової медицини. Згідно з останніми рекомендаціями Європейського товариства кардіологів (2017 р.), медикаментозна терапія усіх хворих, які перенесли IM, має передбачати тривалий прийом подвійної антитромбоцитарної (ацетилсаліцилова кислота та клопідогрель), ліпідознижувальної терапії, $\beta$-адреноблокаторів та інгібіторів АПФ [6].

На амбулаторному етапі вдалось простежити динаміку через 6; 12 та 24 місяці у 52 пацієнток. Відповідно до даних анкети Morisky-Green (D. E. Morisky, L. W. Green, 1986), пацієнток поділили па дві групи: прихильні (27 осіб) та неприхильні (25 осіб) до лікування. Особи обох груп були у середньому подібного віку: прихильні - $(65,26 \pm 1,45)$ та неприхильні - $(68,52 \pm 1,88)$ року. У всіх наявна супутня патологія у поєднанні з АГ тривалістю близько 15 років $((14,5 \pm 2,03)$ року серед прихильних та $(15,66 \pm 1,96)$ року - серед неприхильних) та цукровим діабетом. ЦД було діагностовано у половин жінок, неприхильних до лікування, та у третини прихильних, із дещо більшою тривалістю анамнезу хвороби - $(7,75 \pm 1,16)$ та $(11,80 \pm 3,10)$ року. В однієї третини пацієнток, неприхильних до лікування, в анамнезі уже був IM, на відміну від групи прихильних (лише у 3 пацієнток). що стосується такого фрактора ризику як тютюнокуріння, то у жодної пацієнтки його не було відмічено, а ось надмірна маса тіла була у пацієнток обох груп (IMT у прихильних - $(28,70 \pm 1,35)$, неприхильних $(26,85 \pm 0,72)$ кг/м²). У динаміці маса тіла, як фрактор, що не потребує додаткових засобів, а лише вольових зусиль, не зазнав значних змін у напрямку зменшення. Навпаки, практично у всіх пацієнток із надмірною масою із часом спостерігалось збільшення маси тіла.

Необхідно зазначити, що хворі з групи неприхильних були госпіталізовані у стаціонар значно пізніше - в середньому через $(61,43 \pm 18,90)$ год, на відміну від хворих із групи прихильних, - в середньому через $(15,37 \pm 4,90)$ год. Цей фракт, очевидно, і зумовив нижчий рівень проведеної реваскуляризації міокарда, - лише 5,70 \% серед неприхильних пацієнток проти 28,80 \% серед прихильних. Локалізація інфраркту була однакова в осіб обох груп. Об'єктивно, на момент виникнення IM, ЧСС у обох групах пацієнток не відрізнялась, а ось САТ та ДАТ у прихильних жінок були трохи вищими, ніж у неприхильних -

Таблиця 1. Медикаментозні препарати базової терапії у стаціонарі

\begin{tabular}{|l|c|}
\hline \multicolumn{2}{|c|}{ Прийом препаратів у стаціонарі, \% } \\
\hline Статини & 90,19 \\
\hline Ацетилсаліцилова кислота & 77,45 \\
\hline Клопідогрель/тикагрелор & 89,46 \\
\hline Гепарин & 82,10 \\
\hline Блокатори ß-адренорецепторів & 69,60 \\
\hline Інгібітори АПФ/антагоністи рецепторів до ангіотензину II/APA & 78,92 \\
\hline Нітрати & 59,55 \\
\hline Антагоністи кальцію & 10,50 \\
\hline Сечогінні & 36,51 \\
\hline Спіронолактон & 24,75 \\
\hline Цитопротекторні препарати & 50,49 \\
\hline
\end{tabular}


$(160,40 \pm 6,06)$ і $(95,60 \pm 2,66)$ мм рт. ст. та $(153,40 \pm 6,11)$ i $(89,40 \pm 2,37)$ мм рт. ст. відповідно. Лабораторні показники не значно відрізнялись в обох групах пацієнток, окрім рівня загального холестерину - вищий $(6,46 \pm 2,77)$ ммоль/л у неприхильних, ніж у прихильних $(5,59 \pm 2,99)$ ммоль/л. В останніх також визначалась більша розрахункова маса некрозу.

Порівнюючи показники обох груп, отриманих у динаміці, можемо побачити, що маса тіла та індекс Кетле збільшувались у пацієнток обох груп. Однак достовірними виявили зміни лише у групі неприхильних жінок: через 6 місяців маса у жінок в середньому збільшилась на 1 кг (із $(75,70 \pm 1,52)$ до $(76,40 \pm 1,43)$ кг), індекс Кетле, відповідно, також із $(26,80 \pm 0,73)$ до $(27,15 \pm 0,70) \mathrm{kг} / \mathrm{M}^{2} ;$ а ось через 24 місяці маса тіла у цій же групі підвищувалась у середньому на 5 кг (із $(73,25 \pm 2,90)$ до $(77,25 \pm 1,99)$ кг). Хоча серед групи пацієнток, прихильних до лікування, зміни перелічених показників не мали достовірного значення, все ж таки середні рівні як на початку дослідження, так і в подальшому були вищі: $(80,59 \pm 4,80)$ кг - на момент IM, $(83,94 \pm 5,60)$ кг. Тобто прихильність до подальшого лікування проявляється у вищому ріні прихильності до медикаментозної терапії, а не до модифрікації стилю життя.

Клінічні показники, такі, як частота чСС, САТ та ДАТ були достовірно нижчі серед групи прихильних пацієнток.
Рівень глюкози та холестерину в процесі спостереження знижувався в обох групах, та статистично значимим виявилась лише динаміка показників холестеролу. Необхідно зазначити, що середні рівні показників як на початку дослідження, так і надалі були вищими серед групи неприхильних пацієнток (табл. 2).

За морфофункціональними показниками ехокардіоскопії групи достовірно не різнились. Індекс маси міокарда показав, що в обстежених жінок мала місце гіпертрофрія лівого шлуночка та в середньому переважав концентричний тип ремоделювання міокарда. В динаміці спостереження серед групи пацієнток, прихильних до лікування, показники ехокардіоскопії наближались до притаманних для нормальної геометрії міокарда (табл. 3).

Отримані дані показують, що належне лікування в післяінфарктний період, окрім плацебо-ефекту (суб'єктивне поліпшення самопочуття), забезпечує вірогідний вплив на моророфрункціональний стан міокарда.

Позитивна налаштованість на довготривалу терапію $€$ ключовим моментом у подальшому житті пацієнта після IM. Дані дослідження не показали очікуваної значної різниці між показниками у пацієнток прихильних та неприхильних до лікування, що, очевидно, пов'язано із загальним недостатнім комплаєнсом в умовах реальної клінічної практики.

Таблиця 2. Клінічні та лабораторні показники в неприхильних та прихильних до лікування пацієнток у динаміці

\begin{tabular}{|c|c|c|c|c|c|}
\hline Показник & $\begin{array}{c}\text { Термін спостере- } \\
\text { ження } \\
\end{array}$ & $\begin{array}{l}\text { Неприхильні до лікування } \\
(\mathrm{n}=25)\end{array}$ & $\mathrm{p}$ & $\begin{array}{c}\text { Прихильні до лікування } \\
(\mathrm{n}=27)\end{array}$ & $\mathrm{p}$ \\
\hline \multirow[t]{4}{*}{ Маса тіла (кг) } & $\mathrm{IM}$ & $75,90 \pm 1,90$ & & $80,59 \pm 4,80$ & \\
\hline & 6 мiс. & $76,40 \pm 1,40$ & 0,023 & $77,64 \pm 3,90$ & НД \\
\hline & 12 міс. & $77,10 \pm 1,80$ & НД & $79,65 \pm 4,60$ & НД \\
\hline & 24 мiс. & $77,30 \pm 1,90$ & 0,033 & $83,94 \pm 5,60$ & 0,050 \\
\hline \multirow[t]{4}{*}{ IMT $\left(\mathrm{Kr} / \mathrm{M}^{2}\right)$} & IM & $26,90 \pm 0,72$ & & $29,40 \pm 1,70$ & \\
\hline & 6 мic. & $27,10 \pm 0,70$ & 0,034 & $28,50 \pm 1,32$ & НД \\
\hline & 12 міс. & $27,20 \pm 0,80$ & НД & $29,20 \pm 1,53$ & $\mathrm{HД}$ \\
\hline & 24 мiс. & $24,30 \pm 3,18$ & НД & $30,60 \pm 1,93$ & 0,034 \\
\hline \multirow[t]{4}{*}{ ЧСС (уд./хв) } & $\mathrm{IM}$ & $86,05 \pm 4,30$ & & $85,70 \pm 3,90$ & \\
\hline & 6 міс. & $80,93 \pm 3,78$ & НД & $80,19 \pm 2,90$ & НД \\
\hline & 12 мiс. & $77,35 \pm 3,80$ & 0,041 & $75,17 \pm 2,00$ & 0,034 \\
\hline & 24 міс. & $83,00 \pm 7,90$ & НД & $74,95 \pm 2,00$ & 0,017 \\
\hline \multirow[t]{4}{*}{ САТ (мм рт. ст.) } & IM & $155,42 \pm 8,78$ & & $161,90 \pm 7,07$ & \\
\hline & 6 мiс. & $151,80 \pm 5,22$ & НД & $150,20 \pm 5,56$ & 0,007 \\
\hline & 12 мiс. & $152,30 \pm 5,93$ & НД & $146,09 \pm 4,99$ & 0,010 \\
\hline & 24 mic. & $153,30 \pm 8,82$ & НД & $141,43 \pm 4,97$ & 0,001 \\
\hline \multirow[t]{4}{*}{ ДАТ (мм рт. ст.) } & $\mathrm{IM}$ & $89,58 \pm 2,57$ & & $95,95 \pm 3,11$ & \\
\hline & 6 мic. & $89,80 \pm 1,45$ & НД & $91,20 \pm 2,90$ & 0,050 \\
\hline & 12 мic. & $89,00 \pm 1,94$ & НД & $88,48 \pm 1,81$ & 0,003 \\
\hline & 24 мiс. & $91,25 \pm 3,48$ & НД & $86,19 \pm 2,28$ & 0,001 \\
\hline \multirow[t]{4}{*}{ Глюкоза (ммоль/л) } & $\mathrm{IM}$ & $7,01 \pm 0,70$ & & $6,98 \pm 0,84$ & \\
\hline & 6 мic. & $6,53 \pm 0,54$ & НД & $6,60 \pm 0,57$ & НД \\
\hline & 12 міс. & $6,81 \pm 0,68$ & НД & $6,42 \pm 0,42$ & НД \\
\hline & 24 мic. & $7,09 \pm 1,28$ & НД & $6,18 \pm 0,31$ & НД \\
\hline \multirow[t]{4}{*}{ Холестерол (ммоль/л) } & $\mathrm{IM}$ & $6,86 \pm 0,50$ & & $5,83 \pm 0,35$ & \\
\hline & 6 мic. & $5,76 \pm 0,34$ & 0,018 & $4,87 \pm 0,32$ & 0,033 \\
\hline & 12 міс. & $6,02 \pm 0,32$ & 0,021 & $4,89 \pm 0,29$ & 0,050 \\
\hline & 24 мiс. & $6,25 \pm 0,47$ & НД & $4,71 \pm 0,39$ & 0,049 \\
\hline
\end{tabular}

Примітка. НД - різниця показників не достовірна. 
ISSN 1681-276Х. ВІСНИК НАУКОВИХ ДОСЛІДЖЕНЬ. 2018. № 1

Таблиця 3. Зміни показників геометрії серця у динаміці

\begin{tabular}{|c|c|c|c|c|}
\hline Термін від IM & Неприхильні долікування (n=25) & $p$ & Прихильні до лікування (n=27) & $p$ \\
\hline \multicolumn{5}{|c|}{ Індекс маси міокарда, г/м² } \\
\hline IM & $120,50 \pm 7,06$ & & $132,5 \pm 6,5$ & \\
\hline 6 міс. & $124,30 \pm 7,09$ & НД & $130,9 \pm 8,01$ & НД \\
\hline 12 міс. & $98,70 \pm 14,50$ & 0,050 & $116,09 \pm 10,7$ & НД \\
\hline 24 мiс. & $49,90 \pm 14,10$ & 0,000 & $87,9 \pm 14,6$ & 0,019 \\
\hline \multicolumn{5}{|c|}{ Відносна товщина стінок, од. } \\
\hline IM & $0,50 \pm 0,02$ & & $0,50 \pm 0,02$ & \\
\hline 6 мiс. & $0,53 \pm 0,02$ & 0,025 & $0,47 \pm 0,02$ & 0,040 \\
\hline 12 мiс. & $0,54 \pm 0,02$ & НД & $0,47 \pm 0,02$ & НД \\
\hline 24 мic. & $0,56 \pm 0,03$ & НД & $0,46 \pm 0,02$ & НД \\
\hline
\end{tabular}

Примітка. НД - різниця показників не достовірна.

Висновки 1. У жінок спостерігається недостатній рівень прихильності до наступної вторинної профілактики на амбулаторному етапі лікування й у більшості з них зберігається лише часткова прихильність, особливо через рік після перенесеного IM.

2. Встановлено дуже низьку прихильність до немедикаментозних методів вторинної профілактики та заходів із корекції фракторів ризику і модифрікації стилю життя.
3. Отримані результати ще раз вказують на необхідність оптимізації організаційно-профрілактичних заходів на амбулаторному етапі. Можливо стратегія переходу в роботі з пацієнтами від "комплаєнсу до конкордансу" дозволить покращити вторинну профрілактику інораркту міокарда.

Перспективи подальших досліджень полягають в оптимізації менеджменту інфраркту міокарда на амбулаторному етапі.

\section{СПИСОК ЛІТЕРАТУРИ}

1. Проблеми здоров'я і тривалості життя в сучасних умовах : посібник / за ред. А. П. Дорогой, Т. С. Манойленко, І. Л. Ревенько, Г. М. Дорохіна. - К., 2017. - 190 с.

2. Дудник С. Серцево-судинні захворювання в Україні: прогнози - невтішні / С. Дудник // Ваше здоров'я. - 2015. - № 1-2. - C. $18-19$

3. Коваленко В. М. Срес і хвороби системи кровообігу : посібник / за ред. В. М. Коваленко, В. М. Корнацького. - К., 2015. -207 c.
4. Trends in myocardial infarction secondary prevention: The National Health and Nutritional Examination Survey (NHANES), 1999-2012. I N. S. Shah, M. D. Huffman, H. Ning, D. M. Llloyd-Jones // Journal of American Heart Association. - 2015. - No. 4. - P. 1-12.

5. Пархоменко Н. А. Новое слово в комбинированной терапии ишемической болезни сердца / Пархоменко Н. А. // Здоров'я України. - 2017. - № 5. - С. 12-13.

6. 2017 ESC Guidelines for themanagement of acute myocardial infarction in patients presenting with ST-segment elevation // European Heart Journal. - 2017. - P. 1-66.

Отримано 04.01.18

(OM. V. Hrebenyk, O. I. Levchyk, O. I. Kotsyba, V. R. Mykulyak, L. Yu. Bidovanets, V. A. Dudarenko

WOMEN'S LONG-TERM SECONDARY PREVENTION ADHERENCE AFTER THE MYOCARDIAL INFARCTION

Summary. The myocardial infarction (MI) is the reason of high mortality, disability and significant financial charges all over the world. Every year in Ukraine more than 50 thousand incidences of $\mathrm{Ml}$, and $50 \%$ of these patients dye for next 5 years. Thus, the optimization of secondary prevention arrangements (such as life style modification, the following medicine therapy adherence) has the key meaning in these patients' survival. Thought the compliance in any diseases can be reached only in $20-57 \%$ of incidences, and the literature affirms the sex influence on its level.

The aim of the study - the multimentional evaluation of the women's treatment adherence in post-infarction period.

Materials and Methods. 408 women with acute coronary syndrome of $46-94$ years (average age $(71.30 \pm 0.44)$ years) were observed. The dynamic of the examined indexes after 6,12 , and 24 months could be followed in 52 patients. 2 groups were established accordingly to Morisky-Greens' application (Morisky D.E.,Green L.W., 1986): I (first) -27 persons were adhered, the average age (65.26 \pm 0.44 ) year and the second (II) - unadhered 25 persons, the average age (68.52 \pm 1.88$)$ year. The analysis and the estimation of the clinical, laboratory and instrumental indexes were provided.

Results and Discussion. The comorbidity with arterial hypertension and diabetes mellitus type 2 and the overdue weight were detected in all observed women. Women from the group I were hospitalized earlier (within (15.37 \pm 4.9 ) hours) than in group II (in $(6.45 \pm 18.9)$ hours) with bigger part of revascularization $-28.8 \%$ versus $5.7 \%$; major myocardial necrosis mass; higher indexes of systolic and diastolic blood pressure $(160 \pm 6.06)$ and $(95.6 \pm 2.66)$ versus $(153 \pm 6.11)$ and $(89.4 \pm 2.37) \mathrm{mm} \mathrm{Hg}$ and lower cholesterol 
level - (5.59 \pm 2.99$)$ versus $(6.46 \pm 2.77) \mu \mathrm{mol} / \mathrm{I}$. In dynamics the significant decreasing of the heart rate, systolic and diastolic blood pressure levels and the general cholesterol level were detected and the Echo-indexes approach to the proper normal myocardial geometry.

Conclusions. Women's insufficient adherence level to the following secondary prevention in ambulatory treating stage was observed and mostly only the partly adherence is steel preserved, especially in a year after the MI. Very low adherence to the non-pharmacologic secondary prevention methods and correction risk factors and life style modification arrangements were established. Received results once more assure on necessity of the organization and prevention optimization arrangements on the ambulatory stage. Possibly the regression strategy in patients qualification from "compliance to concordance" allows to advance the secondary MI prevention.

Key words: acute coronary syndrome; myocardial infarction; compliance; treating adherence; secondary prevention; heart remodeling.

СМ. В. Гребеник, Е. И. Левчик, А. И. Коцюба, В. Г. Микуляк, Л. Ю. Бидованець, В. А. Дударенко ГВУз “Тернопольский государственный медицинский университет имени И. Я. Горбачевского” ПРИВЕРЖЕННОСТЬ ЖЕНЩИН К ДЛИТЕЛЬНОЙ ВТОРИЧНОЙ ПРОФИЛАКТИКЕ ПОСЛЕ ИНФАРКТА МИОКАРДА

Резюме Инфаркт миокарда (ИМ) является причиной высокой смертности, инвалидизации и значительных финансовых затрат во всех странах мира. В Украине ежегодно регистрируют около 50 тыс. случаев ИМ, 50 \% из этих пациентов умирают в течение последующих 5 лет. Поэтому оптимизация мер вторичной профилактики (модификация стиля жизни, приверженность к дальнейшей медикаментозной терапии) имеет ключевое значение в выживаемости этих пациентов. Однако комплаенс при любых заболеваниях удается достичь толь у 20-57 \% случаев, по данным литературы, пол имеет влияние на его уровень. Цель исследования - многосракторная оценка приверженности женщин к лечению в послеинорарктный период.

Материалы и методы. Обследовано 408 женщин с острым коронарным синдромом в возрасте от 46 до 94 лет (средний возраст $(71,30 \pm 0,44)$ года). Динамику исследуемых показателей через 6; 12; 24 месяца удалось проследить у 52 пациенток. Согласно анкеты Morisky-Green (D. E. Morisky, L. W. Green, 1986), выделены две группы: первая (I ) - приверженные 27 человек - средний возраст $(65,26 \pm 0,44)$ года и вторая (II) - неприверженные 25 человек - средний возраст $(68,52 \pm 1,88)$ лет. Далее проведен анализ и оценка клинико-лабораторных и инструментальных показателей.

Результаты исследований и их обсуждение. У всех женщин присутствует сопутствующая патология в сочетании с артериальной гипертензией и сахарным диабетом 2 типа, избыточный вес тела. Женщины первой группы быстрее госпитализировали в стационар (через $(15,37 \pm 4,9)$ ч), чем второй группы (через $(6,45 \pm 18,9)$ ч) с большей долей реваскуляризации - 28,8 \% против 5,7 \%; большей массой некроза миокарда; более високими исходными показателями систолического (САД) и диастолического (ДАД) артериального давления $(160 \pm 6,06)$ и $(95,6 \pm 2,66)$ против $(153 \pm 6,11)$ и $(89,4 \pm 2,37)$ мм рт. ст., и болем низким уровнем общего холестерина - $(5,59 \pm 2,99)$ против $(6,46 \pm 2,77)$ ммоль/л. В динамике в этой группе обнаруживалось достоверное снижение ЧСС, САД и ДАД и общего уровня холестерина и приближение показателей эхокардиоскопии к нормальной геометрии миокарда.

Выводы. У женщин наблюдается недостаточный уровень приверженности к следующей вторичной профилактике на амбулаторном этапе лечения и в большинстве из них сохраняется только частичная приверженность, особенно через год после перенесенного ИМ. Установлено очень низкую приверженность к немедикаментозным методам вторичной профилактики и мероприятий по коррекции фракторов риска и модифрикации образа жизни. Полученные результаты еще раз указывают на необходимость оптимизации организационно-профилактических мероприятий на амбулаторном этапе. Возможно стратегия перехода в работе с пациентами от "комплаенса к конкордансу" позволит улучить вторичную профилактику инсраркта миокарда.

Ключевые слова: острый коронарный синдром; инфраркт миокарда; комплаенс; приверженность к лечению; вторичная профрилактика; ремоделирования сердца. 